\title{
NEW CROCODYLIAN REMAINS FROM THE SOLIMÕES FORMATION (LOWER EOCENE-PLIOCENE), STATE OF ACRE, SOUTHWESTERN BRAZILIAN AMAZONIA
}

\author{
RAFAEL GOMES SOUZA \\ Laboratório de Sistemática e Tafonomia de Vertebrados Fósseis, Setor de Paleovertebrados, Departamento de Geologia \\ e Paleontologia, Museu Nacional/Universidade Federal do Rio de Janeiro. Quinta da Boa Vista, s/n ${ }^{\circ}$, \\ São Cristóvão, 20940-040. Rio de Janeiro, RJ, Brazil.rafelsouz@gmail.com

\section{GIOVANNE MENDES CIDADE} \\ Laboratório de Paleontologia, Departamento de Biologia, Faculdade de Filosofia, Ciências e Letras de Ribeirão Preto, \\ Universidade de São Paulo. Av. Bandeirantes, 3900, 14040-901, Ribeirão Preto, São Paulo, Brazil. \\ giovannecidade@hotmail.com
}

\section{DIOGENES DE ALMEIDA CAMPOS}

Museu de Ciências da Terra, Serviço Geológico do Brasil, CPRM, Av. Pasteur, 404, 22290-255, Rio de Janeiro RJ, Brazil. diogenes.campos@cprm.gov.br

\section{DOUGLAS RIFF}

Laboratório de Paleontologia, Instituto de Biologia, Universidade Federal de Uberlândia. Campus Umuarama, Bloco 2D, sala 28, Rua Ceará, s/n, 38400-902, Uberlândia, Minas Gerais, Brazil.driff2@gmail.com

\begin{abstract}
The Solimões Formation (lower Eocene-Pliocene), southwestern Brazilian Amazonia, is one of the most abundant deposits of reptiles from the Cenozoic of Brazil. Eight species of Crocodylia have been described from this formation, including taxa of all the three main extant clades: Gavialoidea (Gryposuchus and Hesperogavialis), Alligatoroidea (Caiman, Mourasuchus and Purussaurus) and Crocodyloidea (Charactosuchus). Here, we describe crocodylian fossil remains collected in 1974 by RadamBrasil Project. Specimens were described and identified to the possible lowermost systematic level. With the exception of the osteoderms, the associated postcranial elements were not identified. It is concluded that at least in one location there may have been co-occurrence of four different morphotypes (Gavialoidea indet., Purussaurus sp., Mourasuchus sp. and taxa of the Brevirostres clade, but not pertaining to Purussaurus or Mourasuchus), suggesting that they could have been contemporaneous, with habitat and niche partitioning.
\end{abstract}

Key words: Crocodylia, Gavialoidea, Alligatoroidea, Solimões Formation, RadamBrasil Project, Cenozoic.

RESUMO - A Formação Solimões (Eoceno inferior-Plioceno) situa-se no sudoeste da Amazônia brasileira, sendo um dos depósitos fossilíferos com maior diversidade em répteis do Cenozoico brasileiro. Foram descritas oito espécies de Crocodylia para esta formação, pertencentes aos três principais clados viventes: Gavialoidea (Gryposuchus e Hesperogavialis), Alligatoroidea (Caiman, Mourasuchus e Purussaurus) e Crocodyloidea (Charactosuchus). Descrevemos aqui fragmentos fósseis coletados em 1974 sob os auspícios do Projeto RadamBrasil na Formação Solimões. Os espécimes foram descritos e identificados em seu nível sistemático menos inclusivo. Com exceção dos osteodermas, os elementos pós-cranianos associados não foram identificados. Conclui-se que pelo menos em uma localidade pode ter havido a co-ocorrência de quatro diferentes morfótipos (Gavialoidea indet., Purussaurus sp., Mourasuchus sp. e táxons do clado Brevirostres mas não pertencentes a Purussaurus ou a Mourasuchus), indicando que eles podem ter sido contemporâneos, com repartição de nichos e de hábitats.

Palavras-chave: Crocodylia, Gavialoidea, Alligatoroidea, Formação Solimões, Projeto RadamBrasil, Cenozoico. 


\section{INTRODUCTION}

The Solimões Formation (lower Eocene-Pliocene) is a wellknown fossiliferous stratigraphic unit containing one of the most diverse and abundant records of Crocodylia of the Cenozoic, with at least one genus representing each of the living groups: Charactosuchus Langston, 1965 (Crocodyloidea); Gryposuchus Gürich, 1912 and Hesperogavialis Bocquentin-Villanueva \& Buffetaut, 1981 (Gavialoidea); Caiman Spix, 1825, Mourasuchus Price, 1964 and Purussaurus Barbosa Rodrigues, 1892 (Alligatoroidea) (Riff et al., 2010). The similarity in taxa occurrence between the Solimões Formation and other South American Miocene fossiliferous units, such as the Urumaco Formation in Venezuela, and the Ituzaingó Formation in Argentina have aroused intriguing biogeographic issues to explain those similarities (for more information see Cozzuol, 2006; Riff et al., 2010; Bona et al., 2013b).

The RadamBrasil Project was one of the most important projects of the Brazilian National Integration Program, with the objective of studying the Brazilian territory in order to understand its natural resources (Brasil, 1973). In 1974, the project explored the Solimões Formation in the eastern portion of the State of Acre, collecting a large variety of fossil specimens, which were deposited in Paleontological Collection of the hitherto Departamento Nacional de Produção Mineral (DNPM; Campos et al., 1976). This collection is now under the responsibility of the Serviço Geológico do Brasil, Companhia de Produção de Recursos Minerais (CPRM). However, most of these specimens have never been formally described (e.g. Latrubesse \& Rancy, 1998).

Fragmentary remains of crocodylians are usually collected in abundance in the Solimões Formation, but generally only well-preserved and/or those representing new taxa are described, whereas many fragments remain unstudied in paleontological collections (e.g. Latrubesse $\&$ Rancy, 1998). However, the description and publication of information about fragmentary remains is necessary as a basis for future works in several areas of paleontology and geology, such as for comparison between faunas and biogeographic analyses (Prasad \& de Broin, 2002; MoraesSantos et al., 2011), to analyse the co-occurrence of species and ecological contents (Agrasar, 2004), to evaluate temporal distribution of taxa (Sato et al., 2012), and for the calculation of oxygen isotope concentration (Billon-Bruyat et al., 2004), among other studies. Furthermore, postcranial elements have recieved much less priority in descriptions because they are usually considered to have less systematic information, as suggested by the minor presence of postcranial characters in phylogenetic analyses (e.g. Brochu, 1997, 2011, 2013).

The aim of this work is to describe new Crocodylia remains from the Solimões Formation, designating them to the less inclusive systematic level possible, and determine their territorial distribution along the fossiliferous localities explored by the RadamBrasil Project, evaluate co-occurrences supported by taphonomic arguments. Moreover, a general discussion about the crocodylian fossil diversity, its possible origins and paleoenvironmental conditions is provided.

\section{MATERIAL AND METHODS}

\section{Geological background}

The Solimões Formation is a well-known by its diverse fossiliferous content, which outcrops out in Amazonas and Acre states, of Brazil (Riff et al., 2010), comprising plants invertebrate and vertebrate remains (Latrubesse et al., 2010). This formation is situated within the Acre, Solimões and Madre de Dios basins; which are exposed in northwestern Brazil, east of Peru and north of Bolivia (Duarte, 2011). The stratigraphic content of the Solimões Formation is characterized by several facies of conglomerates, sandstones and mudstones with fining upward vertical profiles, showing great lateral heterogeneities (Caputo et al., 1971; Brazil, 1976). Further studies (Latrubesse et al., 2010) showed that the sediments of the Solimões Formation are composed mainly by claystones, with calcareous concretions, calcite and gypsum veins, lying in horizontal to sub-horizontal beds that can reach a thickness of over 1,000 m. Cunha (2007) proposed that Solimões Formation lies over the Paleocene marine rocks of Ramon Formation and presents a thickness of 2,200 m.

Dating and thickness of the Solimões Formation adopted in this work are those proposed by Cunha (2007), which corresponds to the Eocene-Pliocene age, with an estimated thickness of 2,200 m related to the Andean Orogeny. This tectonic influence was responsible for the compression of the the Solimões Formation rocks and for the onlap overlapping at its eastern limits. Because of this intense tectonics, the Solimões Formation presents a high quantity of reverse faults (Brazil, 1976). This is in agreement with the Eocene-Oligocene age proposition from the base of the formation (see discussion in Oliveira, 1994) and with the Miocene-Pliocene age to the top of the formation (Latrubesse et al., 2010, see Hsiou \& Albino, 2009 for a discussion about lower-middle Miocene on the top of the formation on some specific localities).

The interpretation of the depositional environment of the Solimões Formation is controversial. The environment was initially attributed to sand bars, channels, and floodplains formed in a fluvial or fluviolacustrine system (Caputo et al., 1971). However, Hoorn (1994) suggested that the sediments of the Solimões Formation resulted from a dynamic environment of shallow lakes and swamps fed and interconnected by a fluvial system of Andean origin, with episodic marine influence (see also Hoorn et al., 2010). Latrubesse et al. (2010) described the formation as being dominantly floodplain-lacustrine-swampy. Considering the information provided by RadamBrasil (Brazil, 1976) and other works, such as Latrubesse et al. (2010), the fluvial paleoenvironment proposed by Caputo et al. (1971), seems to be the most adequate. Further geological and stratigraphic information is provided in the next section, with implications presented on discussion.

\section{Studied area and outcrops}

The studied area comprises the outcrops listed in RadamBrasil Project (Campos et al., 1976) located along Acre River and tributaries between the municipalities of Brasileia 
and Assis Brasil in State of Acre, Brazil (Figure 1). For a better understanding, we kept the locality numbers and names as they are in RadamBrasil Project (Campos et al., 1976).

The description of localities used in this work is entirely based on the description provided by RadamBrasil Project (Campos et al., 1976).

F-84 Chapiama: located on right margin of a tributary of Chapiama stream. Fossils registered in this locality are plants (fragments of wood), fish, turtle and crocodylian remains; all transported material.
F-85 Ipiranga: rapid of Ipiranga, second rapid upstream to the "seringal" (rubber tree farm) São Francisco. The sedimentary rock is described as a conglomerate that crops out in the riverbed during drought. Remains of fish, turtle, crocodylian and mammals (e.g. Toxodon) are reported for this locality. F-90 Pedreira: rapid Pedreira, upstream from the river mouth of stream São Pedro. The sedimentary rock is described as a conglomerate that crops out in the riverbed during drought. Remains of fish, turtles (e.g. Chelus), crocodylians and mammals (e.g. Toxodon) are registered for this locality.

\section{A}

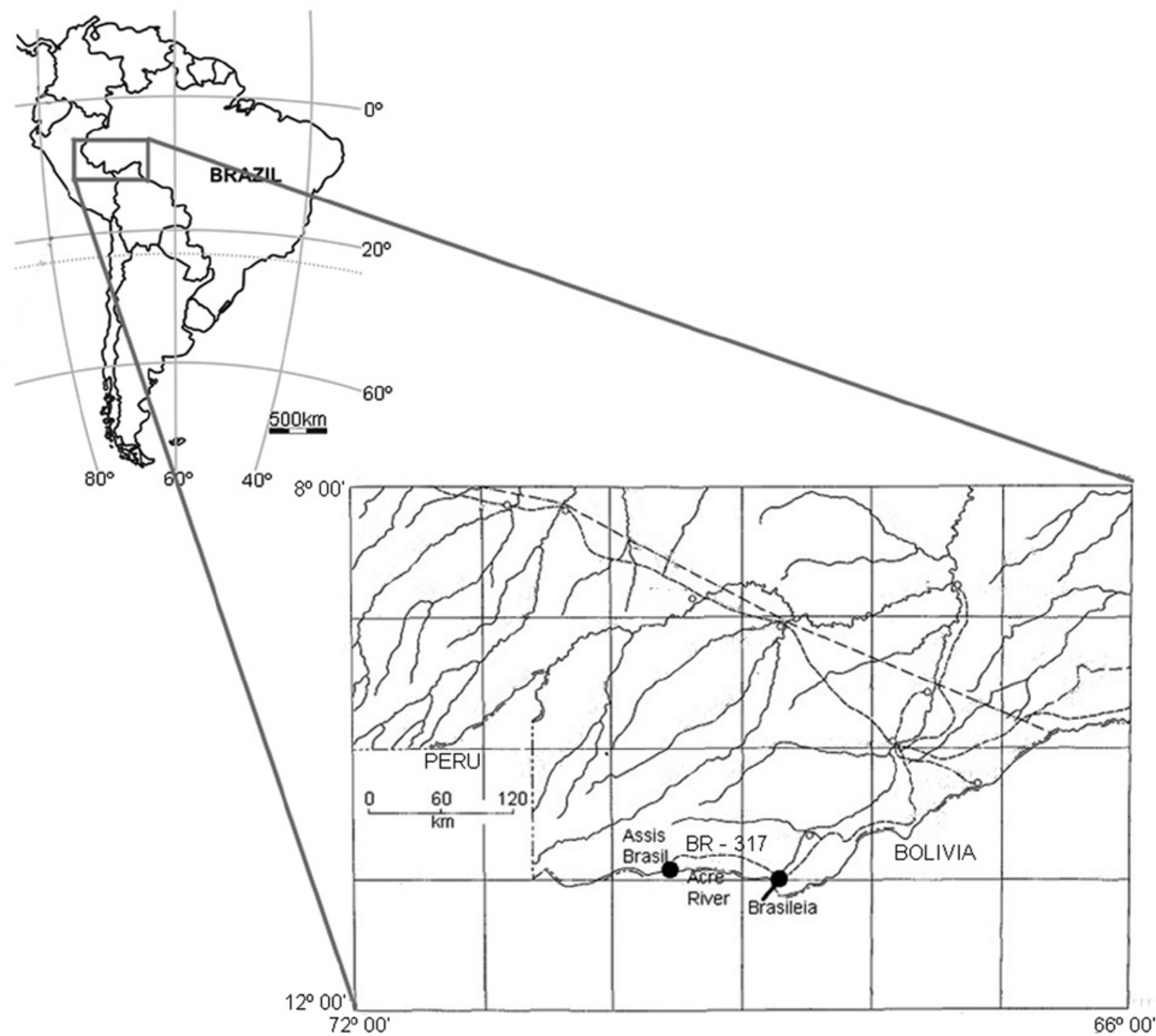

B

\section{Assis Brasil}

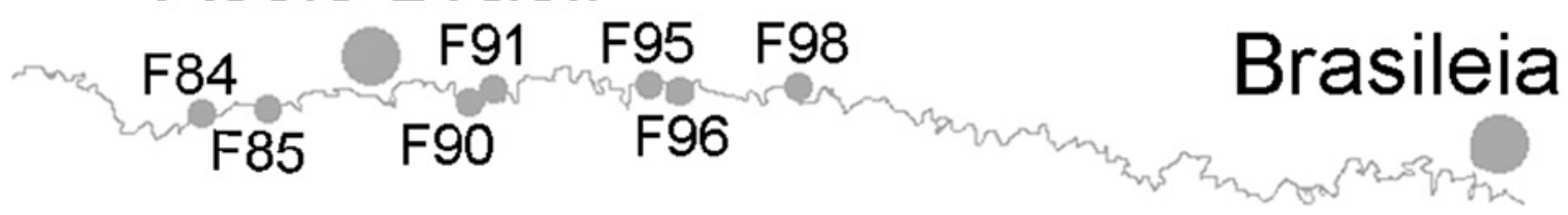

Figure 1. Study area map and the location of outcrops. A, map of South America (modified from Hsiou et al., 2009) indicating Acre State. Zoom area indicating Acre River study area, between municipalities of Assis Brasil and Brasileia (dots) (modified from Brasil, 1976). B, Acre River between municipalities of Assis Brasil and Brasileia (big dots) indicating material localities (small dots). 
F-91 Guajará: downstream the rapid Pedreira. The sedimentary rock is described as an argillaceous siltstone and is exposed as outcrop. Remains of fish, turtles (e.g. Chelus) and crocodylians are registered for this locality.

F-95 Bandeira: fossils collected in this rapid belong to four different points, but only three of them present crocodylian remains: (a) a point situated upstream the rapid, cropping out in the riverbed during drought, with the sedimentary rock being composed by argillaceous siltstone. Only turtle remains are recorded in this point (e.g. Chelus); (b) a point situated immediately downstream the rapid, with fossil remains represented by fish, crocodylians, turtles (e.g. Chelus), bird and mammals (e.g. Delphinidae); (c) a point situated after the first curve of the river, at the left margin downstream the rapid, the sedimentary rock being composed by argillaceous siltstone, cropping out in the riverbed during drought season. Fossil remains of fish, crocodylians, turtle (e.g. Chelus), snake, lizard (e.g. Dracaena) and mammals are recorded from this point; (d) a point situated in the left margin, downstream the point $\mathrm{c}$. The sedimentary rock is a conglomerate that crops out in the riverbed during the drought season. Fossil remains of Mollusca (e.g. Gastropoda and Bivalvia), an Ostracoda, undetermined reptiles, turtles (e.g. Chelus), crocodylians and mammals (e.g. Toxodon and Xenarthra) are recorded from this point.

F-96 Morada Nova: rapid Morada Nova, that crops out in the riverbed on drought season. Remains of crocodylian and mammals are recorded from this point.

F-98 Seringal Sacado: "Seringal" Sacado, a rubber tree farm where the sedimentary rock is exposed. Remains of turtles (e.g. Chelus), crocodylian and fish are registered for this locality.

\section{Studied materials and systematic identification}

Given the fact that few works describe postcranial elements, it was not possible to identify the fragments of vertebral column and appendicular skeleton. Only identification of teeth, cranial fragments and osteoderms from the RadamBrasil Project (Campos et al., 1976) was made.

Among the material collected by RadamBrasil Project and housed at Museu de Ciências da Terra, Serviço Geológico do Brasil - CPRM, only those with a registration number were submitted to analysis (50 specimens). In the time of the original inclusion of these specimens in the collection, they received catalogue numbers under the acronym "DGM" (Divisão de Geologia e Mineralogia). This collection is currently allocated in the Museu de Ciências da Terra,

Table 1. Skeleton parts of the studied material. All numbers are from DGM Collection.

\begin{tabular}{cl}
\hline Categories & \multicolumn{1}{c}{ Referred material } \\
\hline \multirow{2}{*}{ Osteoderms } & $968 ; 969 ; 970 ; 1052 ; 1073 ; 1084 ; 1146 ; 1147 ;$ \\
& $1173 ; 1208 ; 1210 ; 1234 ; 1221 ; 1259 ; 1284$ \\
& $962 ; 963 ; 964 ; 965 ; 966 ; 1053 ; 1054 ; 1055 ;$ \\
Teeth & $1056 ; 1058 ; 1060 ; 1072 ; 1080 ; 1128 ; 1129 ;$ \\
& $1134 ; 1167 ; 1180 ; 1194 ; 1206 ; 1209 ; 1225 ; 1262$ \\
Cranial remains & $1081 ; 1141 ; 1143 ; 1215 ; 1252 ; 1266$ \\
Mandibular remains & $957 ; 958 ; 1082 ; 1217 ; 1291 ; 1410$ \\
\hline
\end{tabular}

under the responsibility of the Brazilian Geological Survey (CPRM), but the specimens still have the acronym given originally. The studied material (Table 1) was divided in four categories: osteoderms (15); teeth (23); cranial elements (6); mandibular elements (6).

The teeth analyzed in this paper were grouped in three morphotypes (Gavialoidea, Purussaurus and the clade non-Purussaurus Brevirostres). These morphotypes were recognized by comparing with descriptions and figures of literature dealing with identification and description of teeth (e.g. Prasad \& de Broin, 2002; Aguilera et al., 2006; Delfino $\&$ de Voz, 2010). Some register numbers do not represent only one individual tooth, but rather a set of several teeth.

The cranial elements have their identification based on descriptions and diagnosis from previous published species (e.g. Price, 1964; Langston, 1965; Riff \& Aguilera, 2008; Bona et al., 2013a).

The identification of the osteoderms was based on external features, provided by Brochu et al. (2007), Langston, (2008) and Scheyer \& Moreno-Bernal (2010).

\section{RESULTS}

\section{General preservation pattern}

As a general preservation status among the teeth, the crowns are well-preserved, although in some cases, the apex is broken and, in all studied teeth, the root is not preserved. The enamel is well preserved in all teeth, and in the morphotypes that exhibit wrinkles and denticles, those are also well preserved. The teeth from the locality F-84 (DGM 1128-R, DGM 1129-R and DGM 1134-R), with the exception of one small and well-preserved teeth attributed to Gavialoidea from the set DGM 1129-R, present angular fractures near the base or in the apex, while also presenting cracks and outworn signals on the enamel. From F-90, the teeth (DGM 1053-R, DGM 1054-R, DGM 1055-R, DGM 1056-R, DGM 1058-R, DGM 1060-R and DGM 1180-R), with exception of one tooth from DGM 1060-R, present the same condition described earlier, although with a more intensive preservational damage such as outworn signals. For example, the tooth DGM 1053-R is broken in half, presenting angular fractures with rounding extremities, while the tooth DGM 1054-R presents well-marked and developed triangular fractures in the base.

The teeth of the F-91 locality (DGM 1209-R) are well preserved with signals of fractures only near the base and with smooth signals of outworn. The teeth from F-98 share this condition too, with exception of one tooth attributed to Gavialoidea, which is well marked and developed, DGM 964-R, DGM 965-R, DGM 966-R and DGM 1262-R share this differential preservation described by F-95b, with all teeth presenting outworn signals on the enamel. The small and slender teeth (e.g. DGM 966-R) are the best preserved, presenting only broken roots and the outworn signals on the enamel. The other ones are tall and large, presenting several angular fractures in the apex and in the base, as in DGM 963R and DGM 1080-R, for example. 
The cranial remains are all portions of isolated bones of the skull or the mandibles. These remains consist of fragments generally badly preserved but yet retaining diagnostic features, with only four (DGM 1082-R, DGM 1141-R, DGM 1143-R, and DGM 1215-R) being highly unsuitable for identification due to poor preservation. Those remains are skull roof and mandibular fragments, which present angular fractures in their fragmented extremities, outworn signals in the periosteum and some rounding in the extremities.

The osteoderms in their general aspect present outworn signals in the external surface, but are well preserved with margins, keel and ornamentation preserved whenever they are present (e.g. DGM 1208-R). Four osteoderms could not be identified due to their poor preservation (DGM 1036-R, DGM 1038-R, DGM 1052-R, and DGM 1147-R), being very small fragmentary pieces with diverse sizes, without any diagnostic feature preserved. The large-sized osteoderms (e.g. DGM $1259-\mathrm{R}$ ) present some signals of rounding in the extremities, while the smaller ones (e.g. DGM 1284-R) present angular fractures in its margins.

\section{Morphological descriptions and systematics}

\section{Clade CROCODYLIFORMES Hay, 1930}

CROCODYLIFORMES indet.

(Figure 2A)

Material. DGM 1052-R, DGM 1082-R, DGM 1084-R, DGM 1141-R, DGM 1143-R, DGM 1147-R, DGM 1208-R, DGM 1215-R, DGM 1221-R.

Remarks. Due the existence of two teeth attributed to Sebecidae Simpson, 1937, collected in the Solimões Formation at the Juruá River (Price et al., 1977), this formation present the ocurrence of at least two Crocodyliformes clades: Sebecidae and Crocodylia. However, no diagnostic feature distinguishing the fragmentary material presented here are identified.

Among cranial and mandibular elements, four (DGM 1082-R, DGM 1141-R, DGM 1143-R, and DGM 1215-R) were impossible to identify due to their highly fragmentary status. DGM 1082-R is a fragment $100 \mathrm{~mm}$ long of a largesized mandible, consisting of a portion of dentary without any alveolus and presenting an internal groove that is probably the Meckelian groove. DGM 1141-R is a nine centimeters long cranial bone fragment; due to the presence of a high ornamentation on show external surface, presence of a small circular articulation and an internal large foramen, we tentatively interpret this material as a jugal bone, with the foramen probably being the jugal foramen. DGM 1143-R is a circular piece of bone with $160 \mathrm{~mm}$ in length presenting an extensive ornamentation on external surface with big and shallow pits, but it was not possible to establish what bone it is. DGM 1215-R is a rectangular bone $100 \mathrm{~mm}$ in length with scarce ornamentation on and with a very white coloration on the surface, contrasting with the dark color of the other bones; due to its fragmentary status, however, it was not possible to establish what bone is this.

The osteoderms attributed to Crocodyliformes indet. (DGM 1084-R, DGM 1208-R, and DGM 1221-R) present a rectangular to sub-circular shape with a small midline keel, an anterior facet of articulation and deep pit ornamentation (e.g. Figure $2 \mathrm{~A})$.

DGM 1084-R, the smallest one, has a rectangular shape with no more than $40 \mathrm{~mm}$ in the major length, being very thin in the dorso-ventral axis, with very deep pits and a small posterior keel. DGM 1208-R, one of the best preserved specimens, is $50 \mathrm{~mm}$ in length and has a white coloration like that of DGM 1215-R, although this material presents a rectangular shape, with an anterior facet of articulation, and shallow pits that occupy all dorsal surface and a slight sinuous midline keel that raises from the posterior margin, reaching the middle portion of the osteoderm (Figure 2A). DGM 1221$\mathrm{R}$, in general aspects of external surface and size, resembles DGM 1084-R; however, DGM 1221-R is more square-shaped with a well-marked anterior facet of articulation, a small keel in the midline and a small postero-lateral projection on the posterior margin.

Two very poorly preserved osteoderms (DGM 1052-R and DGM 1147-R) consist of fragments of compact bones with a smooth surface in at least one side. They were classified as Crocodyliformes indet. due to their fragmentary status that do not allow better identification. DGM 1052-R is a portion of the corner of a square-like osteoderm, exhibiting a notable difference between the thicknesses of the margins to the center; the latter is almost three times thicker than the former. This material exhibits some marks of desiccation. DGM 1147$\mathrm{R}$ is the medial portion of an osteoderm; its smooth portion exhibits some parallel, overlapping scratches.

\section{Order CROCODYLIA Gmelin, 1789 (sensu Benton \& Clark, 1988) \\ Superfamily GAVIALOIDEA Hay, 1930}

GAVIALOIDEA indet. (Figures 3A-E, 4A-B)

Material. DGM 957-R, DGM 958-R, DGM 966-R, DGM 1060-R, DGM 1129-R, DGM 1167-R, DGM 1206-R, DGM 1209-R, DGM 1225-R.

Remarks. The teeth (DGM 966-R, DGM 1060-R, DGM 1129-R, DGM 1167-R, DGM 1206-R, DGM 1209-R, DGM 1225-R.) was identified based on previous teeth descriptions of Gavialoidea (e.g. Lull, 1944; Gasparini, 1968; Buffetaut, 1985; Langston \& Gasparini, 1997; Brochu, 2004; Delfino et al., 2005; Jouve et al., 2006, 2008; Delfino \& de Voz, 2010), and show the following characteristics: long, slender, strongly longitudinally recurved crowns (Figures 3A-C) with a weak longitudinal fluting anteriorly and delicate longitudinal striae posteriorly (Figure 3D); crowns broad lentoid in cross section, with longer axis oriented transversely in the anteriormost teeth and the crown is slightly oblique in those behind (Figure 3E); sharp, unserrated carinae dividing the crowns into almost equal halves (Figures 3A-C). 

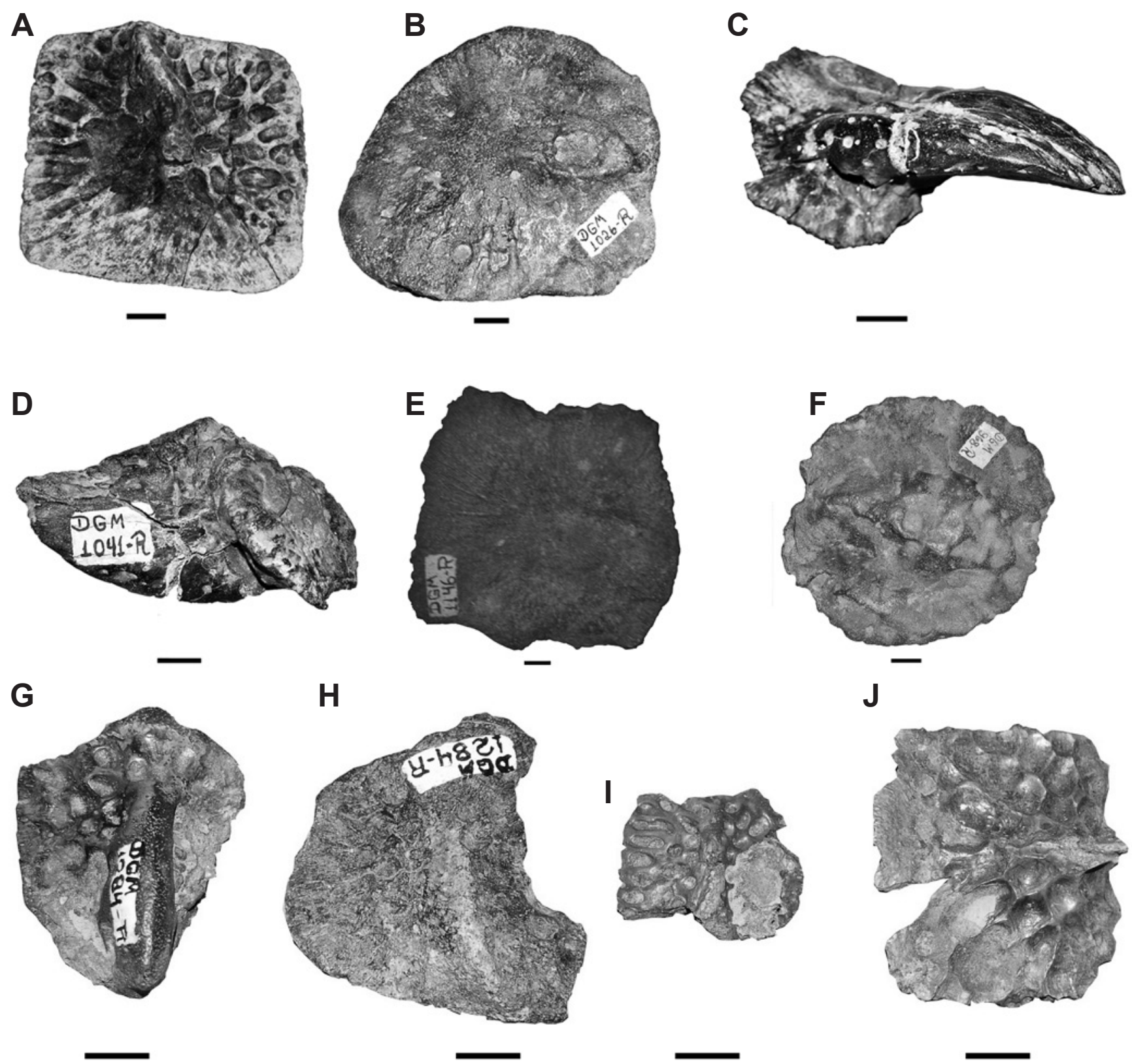

Figure 2. A, Crocodylia indet., DGM 1208-R, osteoderm in dorsal view. B-D, Mourasuchus sp., B, DGM 1026-R, nuchal shield osteoderm in dorsal view; C, DGM 1041-R, osteoderm in anterior view; D, DGM 1041-R, osteoderm in lateral view. E, Purussaurus sp., DGM 1146-R, osteoderm in dorsal view. F, Gavialoidea cf. Gryposuchus, DGM 968-R, osteoderm in dorsal view. G-J, Gavialoidea indet., G, DGM 1284-R first one, in dorsal view; H, DGM 1284-R second one in dorsal view; I, DGM 1284-R third one in dorsal view; J, DGM 1284-R fourth one in dorsal view. Scale bars = $10 \mathrm{~mm}$.

The mandibular elements attributed to Gavialoidea are represented by the specimens DGM 957-R and DGM 958-R (Figures 4A-B) and can be assigned to Gavialoidea indet. due to the length of the partially preserved anterior splenial process (Brochu, 1997). DGM 957-R is the posterior end of a mandibular symphysis with the right dentary and splenial preserved; the splenial points anteriorly and the dentary preserves three alveoli, which have a rounded shape. DGM 958- $\mathrm{R}$ is a posterior end of mandibular symphysis with the left dentary and splenial preserved; the splenial points anteriorly and there are seven alveoli preserved in the dentary.
Gryposuchus Gürich, 1912

Gryposuchus sp.

(Figures 2F-J, 4C-F)

Material. DGM 968-R, DGM 1081-R, DGM 1266-R, DGM 1284-R, DGM 1410-R.

Remarks. Material comprises an incomplete lower jaw (DGM 1410-R) and an associated osteoderm series (DGM 1284-R). Additionally, the following materials are assigned as Gavialoidea cf. Gryposuchus: two cranial fragments of the 
A
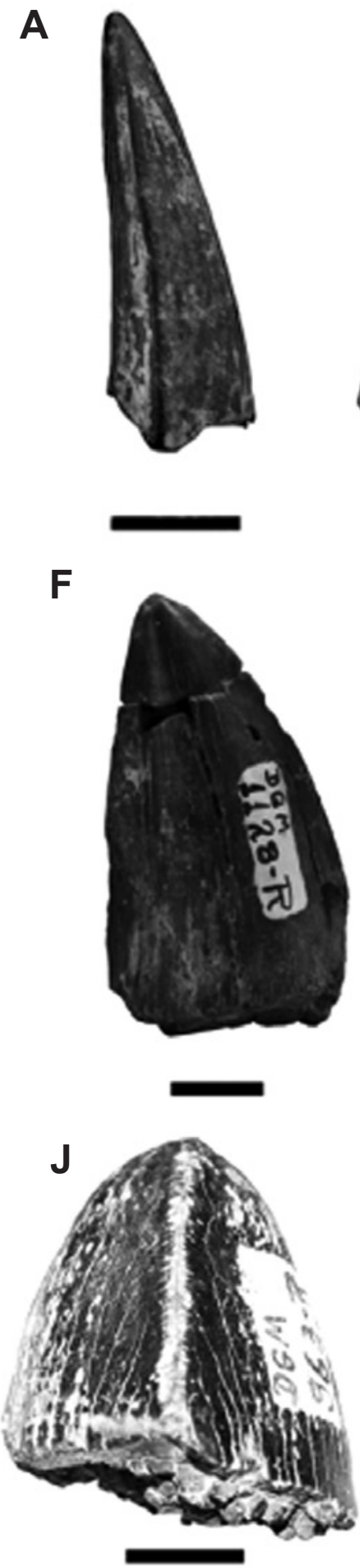

$\mathbf{F}$
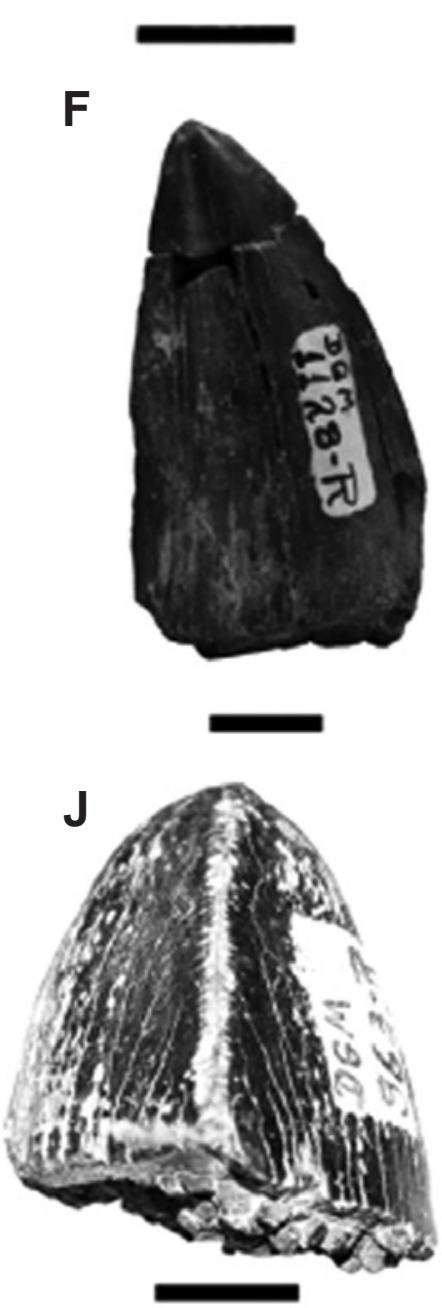


D

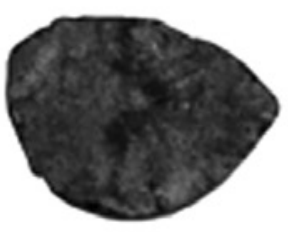

E

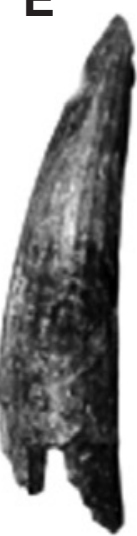

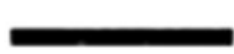

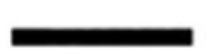

G
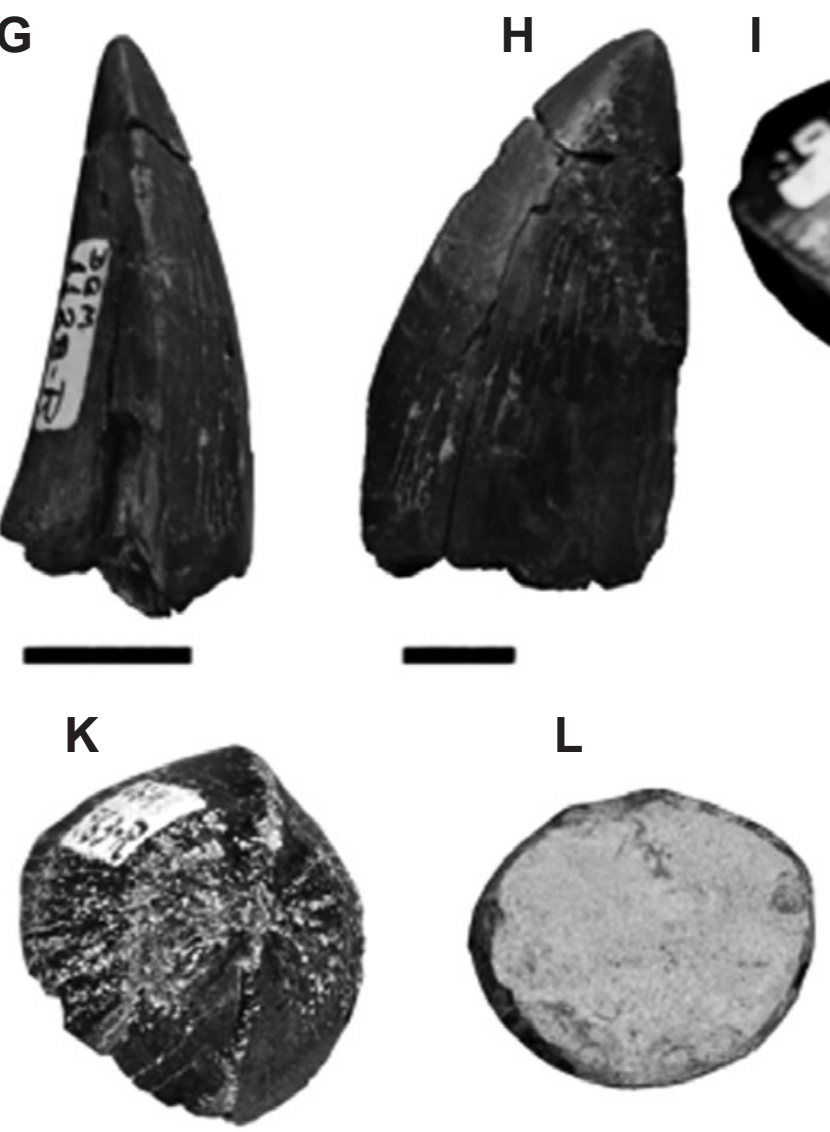

I

Figure 3. Teeth morphotypes: A-E, Gavialoidea; F-I, Purussaurus; M, Brevirostres. A-D, DGM 1060-R, tooth in anterior, labial, posterior, and transverse section, respectively; E, DGM 1194-R, tooth in anterior view. F-H, DGM 1128-R, tooth in lingual, anterior and labial view, respectively; I, DGM 1194-R tooth in apicobasal view, elucidating the presence of denticles (false ziphodonty); J-K, DGM 963-R tooth in anterior and apical views respectively; L, DGM 1206-R tooth in ventral view with subcircular cross section. M, DGM 1206-R, tooth in labial view. Scale bars $=10 \mathrm{~mm}$.

skull roof (DGM 1266-R, and DGM 1081-R) and an isolated osteoderm (DGM 968-R). The DGM 1410-R is a partial lower jaw composed only by a dentary lacking most of the posterior part of the right mandibular ramus and the distal end of the left mandibular ramus. It is partially embedded in the conglomerate matrix, because its fragile condition the rock was preserved in its ventral portion. The splenial participates in the symphysial region issuing a long, wedge-shaped anterior process stretching along ten alveoli (Figures 4C-D). The symphysial region has $212 \mathrm{~mm}$, whereas the preserved 
post-symphysial portion of the left ramus is $85 \mathrm{~mm}$ long; the lateral margins of dentaries are virtually parallel until the end of the symphysis, whereas in the left ramus the posterior portion the dentary curves laterally. There is one broad portion in the symphysis between the $7^{\text {th }}$ and $8^{\text {th }}$ alveoli with $22 \mathrm{~mm}$ wide and one narrower portion between the $4^{\text {th }}$ and $5^{\text {th }}$ alveoli, with $20 \mathrm{~mm}$ wide (Figures 4C-D). Eleven alveoli are present in the preserved portion of right dentary and 22 alveoli in the left portion, of which 19 pertain to the entire symphysis and 12 to the portion formed exclusively by the dentary suture (Figures 4C-D). It is important to note that the dentary do not fuse at the first pair of alveoli. The dentition is homodont, with subcircular, conical and sligtly posteriorly curved teeth. The teeth are inserted in circular alveoli and posseses longitudinal striated crowns lacking serrations in their margins. The alveoli project laterally in collars, with the exception of $1^{\text {st }}$ and $4^{\text {th }}$ alveoli which project dorsally. The collars are formed by the presence of indentation between the alveoli. This feature occurs from the first alveolus until the $12^{\text {th }}$ one. After the $12^{\text {th }}$ alveolus this feature is not present and the alveoli become more dorsal than lateral. The distance between the alveoli ranges from 3.5 (between $21^{\text {st }}$ and $22^{\text {nd }}$ ones) to $9 \mathrm{~mm}$ (between $15^{\text {th }}$ and $16^{\text {th }}$ ones), as the antero-posterior diameter of alveoli ranges from 3 (in the $12^{\text {th }}$ alveolus) to $6 \mathrm{~mm}$ (in the first alveolus). DGM 1410-R is classified as Gryposuchus sp. based mainly on the presence of 22 dentary teeth, with the three posterior ones being most post-symphiseal, a feature shared with Gryposuchus colombianus Langston, 1965 and Gryposuchus croizati Riff \& Aguilera, 2008 (see Langston, 1965; Langston \& Gasparini, 1997; Riff \& Aguilera, 2008). Based on the size of this material, it represents probably a juvenile individual.

Only DGM $1284 \mathrm{R}$ is a postcranial element. It comprises a series of four osteoderms, collected associated by one of the authors (D.A.C.). This material (Figures 2G-J) was found associated with the Gryposuchus sp. mandibular element DGM 1410-R, which is described below. Therefore, we attribute this osteoderm series to Gryposuchus sp. the osteoderms labeled DGM 1284-R are flat or slightly convex (Figures 2G-J). One osteoderm (Figure 2G) is irregular, showing a large and pronounced medial keel on the surface. Large pits also cover it. No articular facet is observed. The second osteoderm (Figure 2H) is more rounded, with the right side partially broken. It also shows a median keel, which is less pronounced than in the first one. The surface shows no distinct ornamentation. The third osteoderm (Figure 2I) is the smallest of the four and has a quadrangular outline. The medial keel is short and reaches the posterior margin. The surface shows several large and deep pits. The last osteoderm (Figure 2J) shows a square outline, and has its surface covered by numerous large pits that are not as deep as in the third one. The median keel is reduced and reaches the posterior margin.

The skull roof bones DGM 1266-R (Figure 4E) and DGM $1081 \mathrm{R}$ (Figure 4F) both present a very thin interfenestral bar composed by the parietal between the supratemporal fenestrae, a characteristic assigned to Gavialoidea cf. Gryposuchus as discussed by Riff \& Aguilera (2008).
DGM 1266-R is a posterior portion of frontal and a small anterior portion of parietal; the anteromedial portion of the supratemporal fenestrae are preserved evidencing the small width of the interfenestral bar. DGM 1081-R is formed by parietal and supraoccipital bones. The supraoccipital does not exposes in the skull roof, being posteriorly limited by the parietal bone, which also comprises the very thin intrafenestral bar limiting the preserved medial margin of supratemporal fenestrae. Moreover, the osteoderm DGM 968-R (Figure $2 \mathrm{~F}$ ) is attributed to Gavialoidea cf. Gryposuchus based on osteoderms described by Scheyer \& Moreno-Bernal (2010). DGM 968-R possesses almost $100 \mathrm{~mm}$ in length, a circular shape, a well marked medial keel that extend from both margins and a deep ornamentation on surface.

Clade BREVIROSTRES Zittel, 1890

BREVIROSTRES indet. (Figure 3M, 5A)

Material. DGM 964-R, DGM 965-R, DGM 1080-R, DGM 1129-R, DGM 1167-R, DGM 1206-R, DGM 1209-R, DGM 1225-R., DGM 1291-R.

Remarks. The teeth (DGM 964-R, DGM 965-R, DGM 1080-R, DGM 1129-R, DGM 1167-R, DGM 1206-R, DGM 1209-R, DGM 1225-R) are attributed to the remaining living crocodylian taxa (Crocodyloidea and Alligatoroidea) given to a relatively uniform morphology of simple, non-serrated conical teeth with a constriction at the base of the crown (Prasad \& de Broin, 2002; Figure 3M). It is important to remark that Purussaurus is an exception within Alligatoroidea for having a unique morphology in the tooth enamel, which is going to be detailed posteriorly in this work. The non-Mourasuchus and non-Purussaurus brevirostrines are represented by a mandible DGM 1291-R (Figure 5A) with a short symphyseal region, which is characteristic to this group in contrast to the long symphysis observed among Gavialoidea species (Brochu, 1999). DGM 1291-R is composed by the dentary bone without any preserved alveoli and a small symphyseal region. It has around $200 \mathrm{~mm}$ of lenght and presents in the medial surface an oppening that is interpreted here as Meckelian groove.

Superfamily ALLIGATOROIDEA Gray, 1844 Subfamily CAIMANINAE Brochu, 1999

Purussaurus Barbosa Rodrigues, 1892

Purussaurus sp.

(Figures 2E, 3F-L, 5D)

Material. DGM 962-R, DGM 963-R, DGM 969-R, DGM 970-R, DGM 1053-R to DGM 1055-R, DGM 1058-R, DGM 1060-R, DGM 1072-R, DGM 1128-R, DGM 1134-R, DGM 1146-R, DGM 1167-R, DGM 1180-R, DGM 1194-R, DGM 1206-R, DGM 1209-R, DGM 1210-R, DGM 1217-R, DGM 1225-R, DGM 1262-R. 

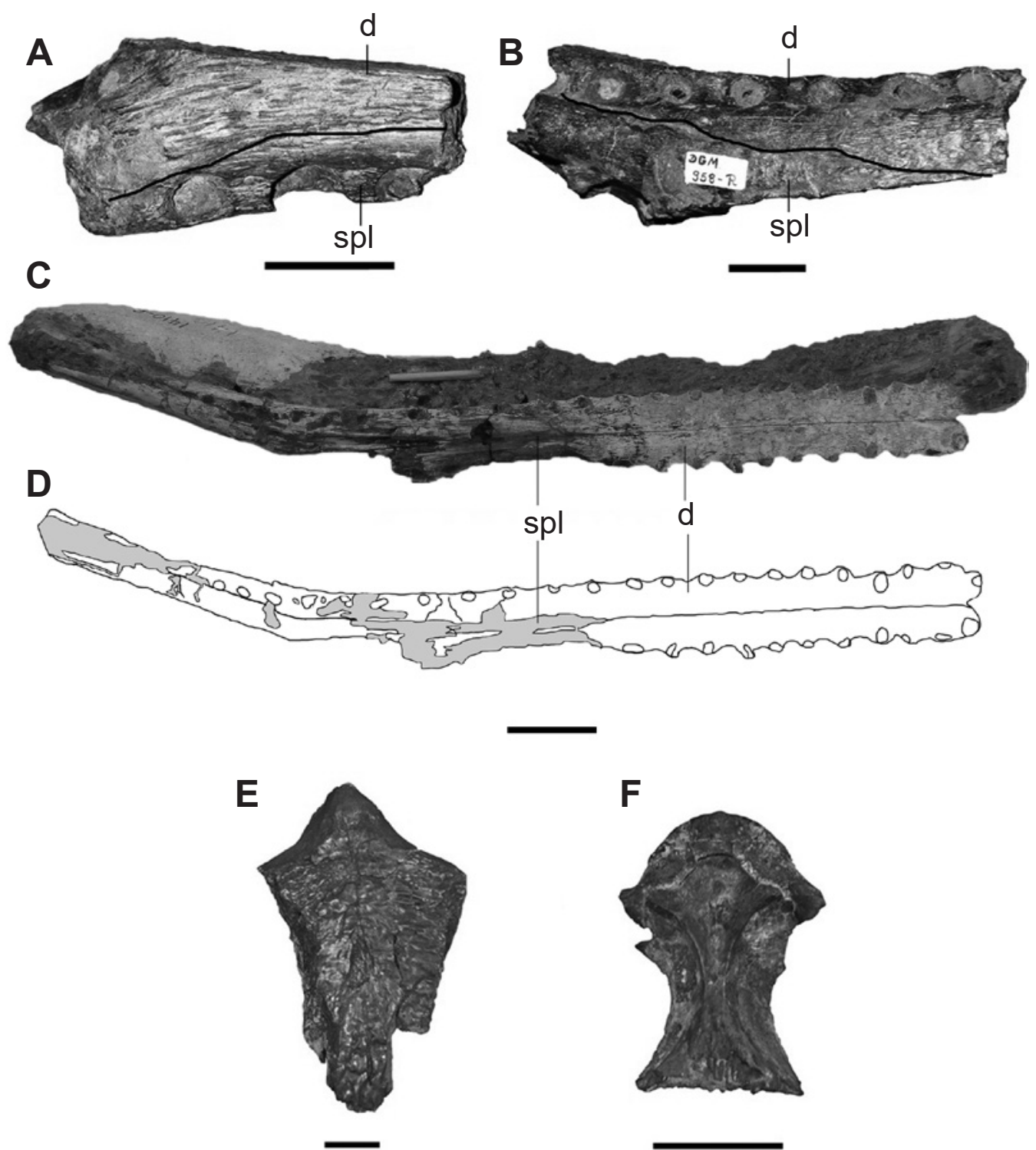

Figure 4. Mandibular and cranial elements in dorsal view attributed to Gavialoidea indet. A, mandibular element DGM 957-R; B, mandibular element DGM 958-R; C, mandibular fragment DGM 1410-R; D, draw of mandibular fragment DGM 1410-R; E, skull roof element (frontal) DGM 1266-R; and, F, skull roof element (parietal) DGM 1081-R. Abbreviations: d, dentary; spl., splenial. Scale bars $=30 \mathrm{~mm}$.

Remarks. The teeth (DGM 962-R, DGM 963-R, DGM 1053-R to DGM 1055-R, DGM 1058-R, DGM 1060-R, DGM 1072-R, DGM 1128-R, DGM 1134-R, DGM 1167-R, DGM 1180-R, DGM 1194-R, DGM 1206-R, DGM 1209-R, DGM 1225-R, DGM 1262-R.) are identified based on Aguilera et al. (2006), who described two morphotypes of teeth for Purussaurus: one consisting of blunted teeth located on the posterior alveoli (Figures 3J-L) and other type consisting of tall, sharp and bent teeth, relatively compressed and bent antero-posteriorly and labio-lingually with a blunted, rounded transverse section (Figures 3F-I). In both morphotypes, the enamel is smooth, with longitudinal and transverse striae along the crown (Figures 3I-J). The teeth have anterior and posterior carinae, showing some denticles projecting perpendicular to each of them (Figures 3I-K). The anterior and posterior carinae, in their turn, are relatively coarse, bearing crenulations usually formed by anastomosing and irregular ridges issued from the main body of the crown, a condition named here as false ziphodont (sensu Prasad \& de Broin, 2002).

The only mandibular element is DGM 1217-R (Figure 5D) that can be tentatively attributed to Purussaurus sp. due to its large size (Aguilera et al., 2006), but does not present any diagnostic feature. This material exhibits two circular alveoli preserved, along with half of the margin of another alveolus. The material is very tall, but thin in the latero-medial section, and can be the most posterior portion of the dentary. In the medial faces, this material exhibits a smooth groove that runs horizontally.

Based on Scheyer \& Moreno-Bernal (2010) we have classified the osteoderms DGM 969-R, DGM 970-R, DGM 1146-R, and DGM 1210-R, Purussaurus sp. due to the sub-rectangular shape with a large medial keel (Figure 2E). DGM 969-R possesses a rectangular shape with an antero-lateral projection of the articular with a large midline 
keel. DGM 970-R consists of four associated osteoderms in a conglomerate rock portion, all of these presenting a rectangular shape with a large midline keel. DGM 1146$\mathrm{R}$ is a rectangular osteoderm with a length of $80 \mathrm{~mm}$, in which the ornamentation is not present and the keel is very short in comparison with other osteoderms of Purussaurus; this variation can be the consequence of differences in the localization of the osteoderms on the dorsal armor. DGM $1210-\mathrm{R}$ is an osteoderm with a rectangular margin parallel to the keel, with the rest of the margins having a curved outline, like in a " $\mathrm{D}$ " shape. The keel is well developed and restricted to the middle portion of the osteoderm.

\section{Mourasuchus Price, 1964}

Mourasuchus sp.

(Figures 2B-D, 5B-C)

Material. DGM 1026-R, DGM 1041-R, DGM 1042-R, DGM 1173-R, DGM 1234-R, DGM 1252-R, DGM 1259-R.

Remarks. One cranial (DGM 1252-R; Figure 5B) and one mandibular (DGM 1042-R; Figure 5C) element are attributed to Mourasuchus sp. DGM 1252-R (Figure 5B) consists of an isolated jugal with a sigmoid shape, exhibiting an accentuated reentrance and is assigned to Mourasuchus sp. due to this feature being present in two species: M. amazonensis Price, 1964 and M. nativus Gasparini, 1985 (see Price, 1964; Bona et al., 2013a). DGM 1042-R (Figure 5C) is a mandible with the characteristic series of small and closely spaced alveoli present in Mourasuchus (Price 1964; Langston, 1965; Bocquentin \& Souza-Filho, 1990).

Five osteoderms have been assigned to Mourasuchus sp. (DGM 1026-R, DGM 1234-R, DGM 1259-R, DGM 1041-R, and DGM 1173-R). Langston (2008) described two morphotypes of osteoderms assigned to Mourasuchus: one broadly rounded, with a high paramedian elevation posteriorly, and the second characterized by smaller osteoderms with a very long keel situated on a small plate. These features of Mourasuchus are easier to identify, being an exception within Crocodylia. In this work, we found both kinds of osteoderms, with three elements exhibiting a morphology that corresponds to the first morphotype (DGM 1026-R, DGM 1234-R, and DGM 1259-R, Figure 2B), while that of other two corresponds to the second morphotype (DGM 1041-R and DGM 1173-R, Figures 2C-D). DGM 1026$\mathrm{R}$ has an irregular shape, with two of its margins being nearly straight whereas the other two have a curved outline. The midline keel is dorsoventrally low. DGM 1234-R has two nearly straight margins, one slightly curved and one deeply curved, whereas the midline keel is dorsoventrally tall. DGM 1259-R has one nearly straighy margin, two parallel margins that are nearly straight but curve deeply towards the midline of the osteoderm in one of the extremities, whereas the other margin is slightly curved throughout its entire outline. In all of these three elements, the margins which are the longest and nearly straight may be the medial margin of the osteoderm, according to the suggestion made by Langston (2008) for Mourasuchus osteoderms from the Urumaco Formation of Venezuela.
The DGM 1041-R is a small osteoderm with a very high, "horn-like" midline keel. The keel is located in the central area of the basal disc of the osteoderm. DGM 1173-R also possess an elevated, "horn-like" keel, larger than the osteoderm with this morphology, the keel of this osteoderms occupies almost entirely the basal surface of the bone, also differently from DGM 1041-4. Langston (2008) suggested that the osteoderms with the long keel could have formed lateral fringes extending longitudinally along the flanks of a Mourasuchus individual, but this cannot be assured, as the exact positions of these osteoderms in Mourasuchus are still not known.

\section{Distribution of taxa across localities}

For a better understanding of the distribution of the fossil taxa across the fossiliferous localities, and to provide new evidence for the co-occurrence hypotheses proposed crocodylians from Acre during the upper Miocene, similarly as proposed, for example, for the Urumaco Formation (Bocquentin-Villanueva \& Buffetaut, 1981; Riff et al., 2010; Scheyer \& Moreno-Bernal, 2010; Scheyer et al., 2013), we listed the material collected in each studied locality (Table 2) and, to enable the comparison between them, we compared the taxa listed with their occurrence for each of these localities (Table 3).

All localities analyzed in this study, with exception of the locality Morada Nova (F-96), have showed at least more than one taxon (Table 2). The Bandeira locality (F-95) has the largest diversity, exhibiting four different taxa: Purussaurus sp., Mourasuchus sp., Gavialoidea indet. and a mandibular fragment assigned to Brevirostres indet. (DGM 1291-R, Figure 5A) that cannot be assignable to either Purussaurus or Mourasuchus and thus may be considered here as a distinct morphotype. The Guajará locality (F-91) may exhibit three to four taxa: Purussaurus sp., Mourasuchus sp. and Gavialoidea indet., teeth from the catalogue number DGM 1209-R here assigned to Brevirostres indet. If this material actually belongs to a Brevirostres taxon other than Mourasuchus, then there would be four different taxa for the Guajará locality. Both localities Chapiama (F-84) and Seringal Sacado (F-98) exhibit the following three taxa: Purussaurus sp., Gavialoidea indet. and Brevirostres indet. non-Purussaurus, the last one represented only by teeth. Additionally, the Ipiranga locality (F-85) exhibits Purussaurus sp. and Mourasuchus sp., while the Pedreira locality (F-90) exhibits Purussaurus sp. and Gavialoidea indet.. Morada Nova locality (F-96) presents only one fossil specimen attributed to Crocodylia indet.

\section{DISCUSSION}

\section{Taphonomy and stratigraphyc control}

As discussed on the geology section, the present work considers at least the uppermost portion of Solimões Formation as a fluvial paleoenvironment, as proposed by Caputo et al. (1971). However, based on outcrops photographs, vertical profiles, well profiles and descriptions (Brazil, 1976; Latrubesse et al., 2010), we observe several overlapping facies of conglomerates, sandstones and 
Table 2. Localities of outcrops and respective material. Locality name and number based on the RadamBrasil Project report (Brasil, 1976). All register numbers of the material are DGM number-R. Register numbers with modified formatting belongs to one of the follow groups: underlined, Gavialoidea; bold, Purussaurus; italic, Mourasuchus; asterisk, Brevirostres; without formatting, Crocodylia indet. The locality F-95 is subdivided in four points $(a, b, c, d)$, three of them $(\mathbf{b}, \mathbf{c}, \mathbf{d})$, with crocodylian remains.

\begin{tabular}{cll}
\hline Locality number & Locality name & \multicolumn{1}{c}{ Material } \\
\hline F-84 & Chapiama & $\mathbf{1 1 2 8} ; \underline{1129 * ; 1134 ; 1141 ; 1143 ;}$ \\
F-85 & Ipiranga & $1194 ;$ \\
F-90 & Pedreira & $1052 ; 1053 ; 1054, \mathbf{1 0 5 5} ; 1056 ; 1058 ; \underline{1060} ; \mathbf{1 1 8 0} ;$ \\
F-91 & Guajará & $1208 ; \underline{1209 * ; 1210 ; 1215 ;}$ \\
& & b: 1146; $1147 ; \underline{1167 * ; 1173 ;}$ \\
& Bandeira & c: $\mathbf{1 0 7 2} ; 1073 ; 1080^{*} ; \underline{1081} ; 1082 ; 1084 ; \underline{1225^{*} ;}$ \\
F-95 & d: $\underline{957} ; \underline{958} ; 962 ; 963 ; 964 * ; 965^{*} ; \underline{966} ; \underline{968}, \mathbf{9 6 9} ; \mathbf{9 7 0} ;$ \\
& & $1234 ; 1252 ; 1259 ; \mathbf{1 2 6 2} ; \underline{1266} ; \mathbf{1 2 8 4} ; 1291^{*} ; \underline{1410 ;}$ \\
F-96 & Morada Nova & $1221 ;$ \\
F-98 & Seringal Sacado & $\underline{1206 * ; 1217 ;}$ \\
\hline
\end{tabular}

Table 3. Taxon occurrence based on material described here for each locality. In this table, Brevirostres do not include Purussaurus and Mourasuchus remains. Legends: $\mathbf{X}$, accounting for the presence of referred taxa; -, absence.

\begin{tabular}{ccccc}
\hline \multirow{2}{*}{ Locality } & \multicolumn{5}{c}{ Taxa } \\
\cline { 2 - 5 } & Gavialoidea & Purussaurus & Mourasuchus & Brevirostres \\
\hline F-84 & $\mathrm{X}$ & $\mathrm{X}$ & - & $\mathrm{X}$ \\
F-85 & - & $\mathrm{X}$ & $\mathrm{X}$ & - \\
F-90 & $\mathrm{X}$ & $\mathrm{X}$ & - & - \\
F-91 & $\mathrm{X}$ & $\mathrm{X}$ & $\mathrm{X}$ & $\mathrm{X}$ \\
F-95 & $\mathrm{X}$ & $\mathrm{X}$ & $\mathrm{X}$ & $\mathrm{X}$ \\
F-96 & - & - & - & - \\
F-98 & $\mathrm{X}$ & $\mathrm{X}$ & - & $\mathrm{X}$ \\
\hline
\end{tabular}

mudstones with fining upward vertical profiles. Based on Miall (1985) and Catuneanu et al. (2009) we preliminarily reinterpreted the uppermost portion of Solimões Formation as a high sinuosity fluvial meandering paleoenvironment. As such, we interpret the conglomerates facies with imbricated gravels $(\mathrm{Gm})$ as the architectural elements gravel bars (GB) or, in some cases, when it appears on the base of a channel, as foreset macroforms elements (FM). The canalized sandstones are interpreted here as lateral accretion bars (LA), while the sandy bedforms (SB) are interpreted as crevasse splays deposits, which could be interbedded with the floodplain fines. The argillaceous siltstone facies can be attributed to overbank fines (OF) or abandoned channels $(\mathrm{CH})$.

The fossil remains attributed to the upper Solimões Formation are found mainly on the conglomerates (FM; e.g. F-85, F-90), but also from $\mathrm{CH}$ and $\mathrm{OF}$ argillaceous siltstone (e.g. F-95b; see section "studied area and outcrops"). However, those occurrences are reported only with the geographical location and rarely with informations about the facies and the outcrop. Thus, no refined stratigraphic data of this unit was available, which hinders the stratigraphic correlations and age estimations for the unit.
The studied material present innumerous evidence for transportation, such as rounded fractures and wear signals post depositional transportation are observed in collected material from F-84. The only probable exception are the fossils preserved on floodplain, whose preservation condition could be the result of trampling, weathering or soil decomposition (Behrensmeyer, 1982). However, considering that those materials are associated with the facies described above, we can infer that they were deposited in the same paleoenvironment, which in this case would be a high sinuosity fluvial meandering (see Miall, 1985 for more complete architectural and paleoenvironment models). Based on Behrensmeyer (1982), the time needed for a meandering fluvial environment to close its fluvial cycle is around some thousands years, a short time if considered in the context of geological time. In this way, it seems likely that specimens represented in this taphocenosis coexisted at least during some thousands years. Corroborating this hypothesis, there is not any reverse fault that could move upward some older facies (see geological map in Brazil, 1976). Besides this contribution, new studies focusing on high resolution stratigraphy, more complete taphonomic analysis, including geological information and all fossil records, are in need to increase our knowledge on Solimões Formation. 

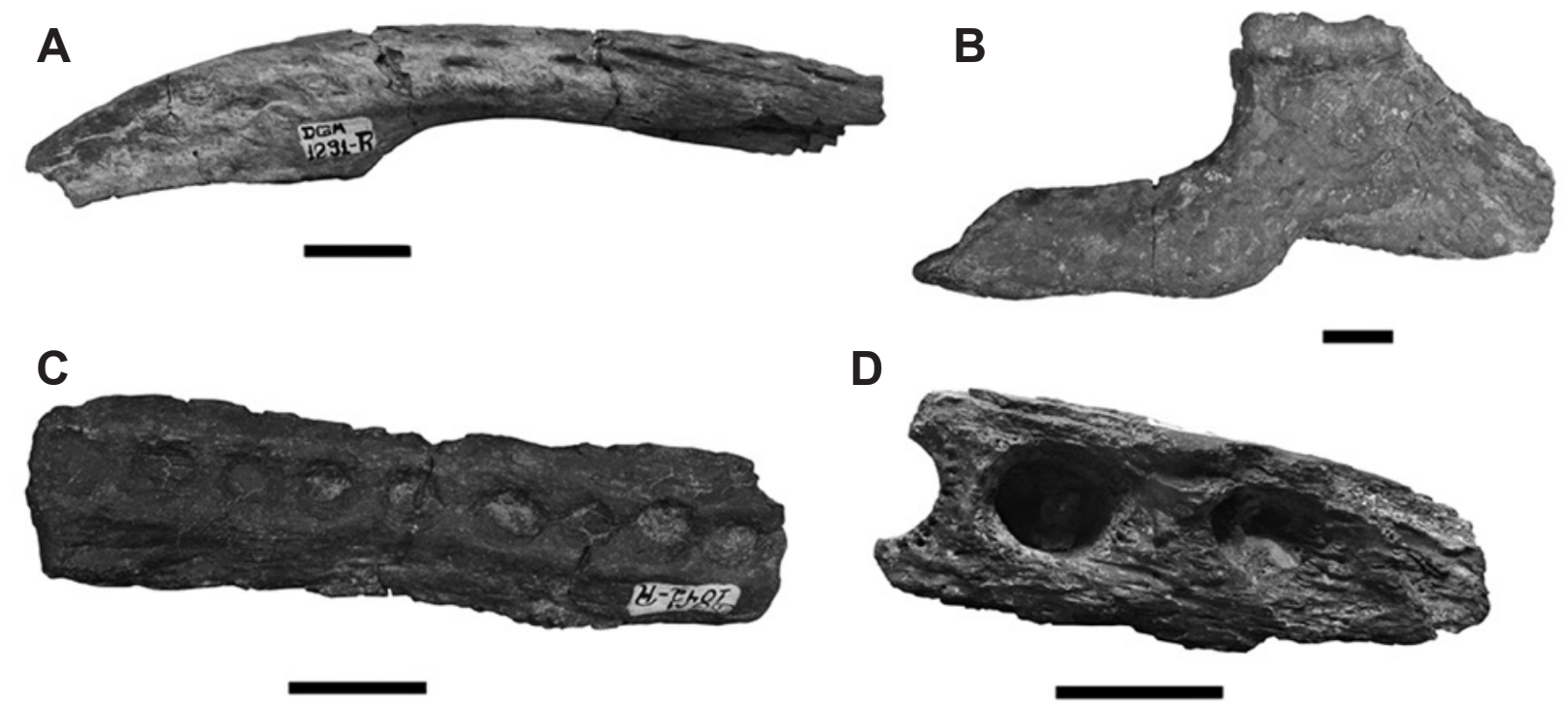

Figure 5. Cranial and mandibular elements attributed to Brevirostres. A, DGM 1291-R, dentary in ventral view; B, Mourasuchus sp. (DGM 1252-R), jugal in laterodorsal view; C, Mourasuchus sp. (DGM 1042-R), dentary in dorsal view; D, Purussaurus sp. (DGM 1217-R), dentary in dorsal view. Scale bars $=30 \mathrm{~mm}$.

\section{Crocodylian remains and its systematic implications}

The practice of using isolated teeth to determine the occurrence of taxa is very common in paleontology (e.g. Prasad \& de Broin, 2002). However, isolated teeth are nearly uninformative for crocodylian taxonomy, so that identification based on this kind of material has been questioned (Kotsakis et al., 2004) or at least cautiously accepted (Delfino \& Rook, 2008). Examples of this practice with crocodylians can easily be found in the literature due to the variety of teeth morphotypes (e.g. Prasad \& de Broin, 2002). However, designations of this kind need caution because teeth morphotypes rarely can be identified to the species level or assigned to a monophyletic group (Prasad \& de Broin, 2002). This practice has never been applied before for crocodylians of the Solimões Formation, but based on previous published species (Riff et al., 2010), the three teeth morphologies presented here the systematic determination. The piscivorous group Gavialoidea, has homodont teeth that are long and slender, with strongly longitudinally recurved crowns and striae on the enamel. The other teeth group, with false ziphodonty, can only pertain to Purussaurus (Aguilera et al., 2006) while the third group, in its turn, is not exclusive to any monophyletic group as it is formed by teeth with the general aspect that most brevirostrine crocodylians possess, so that they were to non-Purussaurus Brevirostres.

Osteoderms are a very difficult category of bone to classify taxonomically, with exception of those of Mourasuchus. More works are in need to a better taxonomic and ecological understanding of this complex structure (e.g. Scheyer \& Moreno-Bernal, 2010). Although the high diversity of crocodylians recorded from the Solimões Formation has been mentioned and discussed by several authors (e.g. Cozzuol, 2006; Riff et al., 2010), it is possible to speculate whether all the species recorded for this Formation have actually coexisted (e.g. Scheyer \& Moreno-Bernal, 2010).
As such, a survey of the stratigraphic origin of the specimens described in this study may help to address this issue, as the occurrence of fossil specimens of different taxa in a given locality increases the possibility that such taxa have coexisted contemporaneously at the same habitat.

\section{Paleoecological implications}

The fossil specimens surveyed in this study indicate the co-occurrence of a minimum of two taxa for each of the localities, with the most diverse locality (Bandeira, F-95) showing the co-occurrence of at least four different taxa. This is congruent with the maximum of three to four crocodylian species that are found in modern communities currently (Langston \& Gasparini, 1997; Brochu, 2001; Scheyer \& Moreno-Bernal, 2010), including the current Amazon and Orinoco river systems in the modern Amazon rainforest (Scheyer \& Moreno-Bernal, 2010). However, this number of crocodylian fossil species for each locality can be underestimated due to the fragmentation of the remains.

This fact reinforce the possibility that several of the crocodylian taxa recorded in the Solimões Formation may have actually occurred contemporaneously and at the same environment during the upper Miocene. However, both these hypotheses should be regarde with some caution due to the possibility of temporal mixture in the outcrops analyzed. The uppermost portion of the Solimões Formation is considered as an upper Miocene unit (Cozzuol, 2006; Latrubesse et al., $2010)$, equivalent to the Huayquerian ( 9-6.8 Ma) of the South American Land Mammal Age - SALMA (Fortier et $a l ., 2014)$. Specifically about the localities analyzed in this study, Latrubesse et al. (2010) considers the Bandeira locality (F-95) to be late Miocene in age due to its vertebrate fossils content. The fossils described in this work do not contradict this assumption. However, Fortier et al. (2014) state that several outcrops of the Solimões Formation are likely to 
have differences in age. The Juruá River, for example, is considered to bear sediments from different ages such as late Miocene-Pliocene, Pleistocene and Holocene (Latrubesse \& Rancy, 1998). As such, the possibility of a temporal mixture on the localities analyzed cannot be ruled out until detailed chronostratigraphic analyses are made on those outcrops.

While it may be said that the existence of different crocodylian taxa in a same outcrop could argue for their sympatric occurrence, it is important to remark that these remains were most likely buried in a different place than that occupied by the alive crocodylian population. As described by Langston (1965) for the crocodylian fauna of the Honda Group, of the middle Miocene of Colombia, crocodylian remains in those depositional environments tended to be carried along the river course until being buried in a downstream site, and there is no reason to think that the deposition in the Solimões Formation would occur differently (also see Behrensmeyer, 1982). One of the items collected at the Bandeira locality (F-95d), a mandibular fragment of a gavialoid (DGM 1410-R), is accompanied with a matrix made of a thin conglomerate (FM), which indicates a medium to high-energy environment. Additionally, the fragmentary nature of the remains reported in this study also argue for a high energy environment which may have carried these remains from certain distances until the deposition site. As such, while it may be said that the co-occurring crocodylians of the outcrops analyzed here inhabited the same paleoenvironment, it would not be reasonable to affirm that they inhabited a same habitat or microhabitat. This assumption is also important because the very facts of habitat heterogeneity, accompanied by habitat and niche partitioning, are some of the reasons proposed to explain the exceptional crocodylian diversity of the Solimões Formation, to be discussed below.

Several explanations have been given in the literature for the remarkable diversity and morphological disparity seen in the Miocene of South America, including the Solimões Formation: a hot, humid weather, suitable for the crocodylian physiology (Brochu, 2011) and generating a high level of primary productivity, which supplied an abundance of prey items for crocodiles. Then, the existence of large water-bodies, like Pebas and Acre systems in the middle and late Miocene, respectively (Hoorn et al., 2010), provided not only a large area for occupation of crocodylian populations as well as a handful of different available habitats. For example, Latrubesse et al . (2010) describe the depositional environment of the Solimões Formation "as dominated by avulsive rivers associated with megafan systems, flood basins (swamps, lakes, internal deltas, and splays)". All those are different habitats that may have offered different ecomorphological conditions, different prey items and, as a consequence, different crocodile forms inhabiting each one of them (Salas-Gismondi et al., 2007; Riff et al., 2010; Scheyer \& Moreno-Bernal, 2010). This diversity of habitats and prey items may respond for the morphological and presumably ecological (niche-partitioning) disparity seen among the crocodylians of the Solimões Formation: the bigsized predator (Purussaurus), longirostrine piscivorous (such as gavialoids Gryposuchus and Hesperogavialis, but also the crocodyloid Charactosuchus), more generalist, medium-sized crocodiles (Caiman) and Mourasuchus, whose paleoecology and feeding habits are yet to be properly defined (Bona et al., 2013a) but have been interpreted as putative passive, filterfeeding animals (Langston 1965, 2008; Tineo et al., 2014). Other units of the Miocene of the Amazon area, such as middle Miocene Pebas Formation of Peru and the upper Miocene Urumaco Formation of Venezuela have also occurrences of these four morphotypes, but differ from the Solimões Formation in having occurrences of basal durophagous caimanines (see Scheyer et al., 2013 and Salas-Gismondi et al., 2015). The middle Miocene Honda Group of Colombia differs from the Solimões Formation by having a putative durophagous aligatorid of uncertain phylogenetic position, Balanerodus logimus, and the occurrence of the terrestrial predator Sebecus (Langston, 1965; Langston \& Gasparini, 1997). The presence of these taxa in these units elevates to six the number of morphotypes occurring in crocodylian taxa during the Miocene in the Amazon region of South America. Whether the absence of the durophagous and terrestrial crocodiliforms in the fossil record of the Solimões Formation is an actual absence or the result of an incomplete sampling is a question to be addressed by future works and collection efforts.

However, for all of those mentioned ecological components to take place, time is an important component, and previous works (e.g. Salas-Gismondi et al., 2007; Scheyer \& Moreno-Bernal, 2010) have mentioned the "long-term stable environment" that had to be present throughout the Cenozoic of the Amazon region to allow the evolution of highly derived forms such as Purussaurus and Mourasuchus to evolve. Additionally, in this context it is interesting to notice, as far as Caimaninae crocodiles are concerned, the co-occurrence of both primitive and derived forms of this lineage in upper Miocene deposits. Recently, Scheyer et al. (2013) described Globidentosuchus brachyrostris from the upper Miocene Urumaco Formation in Venezuela, a species recovered in their phylogenetic analysis as the basalmost Caimaninae. Another example may be the occurrence of "Eocaiman sp." reported by Langston (1965) to the middle Miocene Honda Group of Colombia. These two examples are a suggestion of the long-term stable environment predominant in the tropical zone of South America during the Cenozoic, since such an environment may have allowed the more recent, derived and even "bizarre" forms such as Purussaurus and Mourasuchus to evolve and still co-occur with more basal Caimaninae, such as Globidentosuchus.

\section{CONCLUSION}

The region comprising the current Amazonia was, during the upper Miocene, a very diverse and rich environment, home of one of the most fascinating and intriguing crocodylian faunas. Based on the systematic study made on the RadamBrasil Crocodyliformes materials we conclude that fragmentary material, such as teeth, osteoderms, cranial and mandibular remains are passive of a significant identification. 
Those results together with the preliminarly taphonomic and geological study strengthen the co-occurrence hypothesis of at least four different crocodylian species on the upper Solimões Formation. However, for future works, more taphonomic and stratigraphic studies are needed to corroborate those hypotheses. In addition, systematic studies of fragmentary remains are necessary, focusing especially in more precise and comparative description of postcranial material to elucidate the evolution of crocodylians and to allow a more precise identification of these kinds of fossil material. Additionally, it is probable that paleohistology studies can help in the taxonomy of bone remains, especially osteoderms. All this notwithstanding, this work offers a contribution for a better understanding of the paleoecology of the crocodylians from the Solimões Formation, although it must be stressed that there is very much to be done in the study of this interesting fauna and paleoenvironment.

\section{ACKNOWLEDGMENTS}

We thank the curator of Museu de Ciências da Terra, R.R. Machado and I.T. Yamamoto for the access to the material, G. Muricy (Museu Nacional/Universidade Federal do Rio de Janeiro) and J. Resende (Museu Nacional/Universidade Federal do Rio de Janeiro) for revision and assistance. We also thank K. Bandeira (Museu Nacional/Universidade Federal do Rio de Janeiro) for help in figure's edition. L. Avilla (Universidade Federal do Estado do Rio de Janeiro, UNIRIO), and Laboratório de Mastozoologia (LAMASUNIRIO) helped with the infrastructure and photographic equipment. J.S. Frota, for the donation of several specimen fossils. Thanks, for financial support provided by Programa de Mobilidade Nacional - the Master's Degree scholarship from CNPq and FAPERJ nota 10 (E-26/101.523/2014), and the Doctorate scholarship from CAPES to the author RGS, which enabled the study of material here presented. Also, FAPESP Master's Degree scholarship 2013/04516-1 and CNPq Doctorate scholarship 140808/2016-7 to the author GMC supported this research.

\section{REFERENCES}

Agrasar, E.L. 2004. Crocodile remains from the Burdigalian (lower Miocene) of Gevel Zelten (Libya). Geodiversitas, 26:309-321.

Aguilera, O.A.; Riff, D. \& Bocquentin-Villanueva, J. 2006. A new giant Purussaurus (Crocodyliformes, Alligatoridae) from the Upper Miocene Urumaco Formation, Venezuela. Journal of Systematic Palaeontology, 4:221-232. doi:10.1017/ S147720190600188X

Behrensmeyer, A.K. 1982. Time resolution in fluvial vertebrate assemblages. Paleobiology, 8:211-227. doi:10.1017/ S0094837300006941

Benton, M.J. \& Clark, J.M. 1988. Archosaur phylogeny and the relationships of the Crocodylia. In: M.J. Benton (ed.) The phylogeny and classification of the tetrapods Amphibians, reptiles, birds, Clarendon Press, p. 295-338.

Billon-Bruyat, J.; Lécuyer, C.; Martineau, F. \& Mazin, J. 2004. Oxygen isotope compositions of Upper Jurassic vertebrate remains from lithographic of Western Europe: implications for the ecology of fish, turtles, and crocodylians. Palaeogeography, Palaeoclimatology, Palaecoecology, 216:359-375. doi:10.1016/j. palaeo.2004.11.011

Bocquentin, J.C. \& Souza-Filho, J.P. 1990. O Crocodyliano sulamericano Carandaisuchus como sinonímia de Mourasuchus (Nettosuchidae). Revista Brasileira de Geociências, 23:230-233.

Bocquentin-Villanueva, J. \& Buffetaut, E. 1981. Hesperogavialis cruxenti n. gen. n. sp., nouveau gavialidae (Crocodylia, Eusuchia) du Miocéne supérieur (Huayquerian) d'Urumaco (Venezuela). Geobios, 14:415-419. doi:10.1016/S0016-6995(81)80184-2

Bona, P.; Degrange, F.J. \& Fernández, M.S. 2013a. Skull anatomy of the bizarre Crocodylian Mourasuchus nativus (Alligatoridae, Caimaninae). The Anatomical Record, 296:227239. doi:10.1002/ar.22625

Bona, P.; Riff, D. \& Gasparini, Z.B. 2013b. Late Miocene crocodylians from northeast Argentina: new approaches about the austral components of the Neogene South American crocodylian fauna. Earth and Environmental Science Transactions of the Royal Society of Edinburgh, 103:551-570. doi:10.1017/ S175569101300042X

Brasil, 1973. Projeto RadamBrasil: Parte da folha SC.23 Rio São Francisco e SC.24 Aracaju: geologia, geomorfologia, solos, vegetação e uso potencial da terra. Rio de Janeiro, Departamento Nacional de Produção Mineral, 262 p. (Levantamento de recursos naturais 1 ).

Brasil, 1976. Projeto RadamBrasil: Parte da folha SC.19 Rio Branco: geologia, geomorfologia, pedologia, vegetação e uso potencial da terra. Rio de Janeiro, Departamento Nacional de Produção Mineral, 464 p. (Levantamento de recursos naturais 12).

Brochu, C.A. 1997. Morphology, fossils, divergence timing, and the phylogenetic relationships of Gavialis. Systematic Biology, 46:479-522. doi:10.2307/2413693

Brochu, C.A. 1999. Phylogenetics, taxonomy, and historical biogeography of Alligatoroidea. Journal of Vertebrate Paleontology, 19:9-100. doi:10.1080/02724634.1999.10011201

Brochu, C.A. 2001. Congruence between physiology, phylogenetics and the fossil record in crocodylian historical biogeography. In: G.C. Grigg; F. Seebacher \& C.E. Franklin (eds.) Crocodylian biology and evolution, Surrey Betty and Sons, p. 9-28.

Brochu, C.A. 2004. A new Late Cretaceous gavialoid crocodylian from eastern North America and the phylogenetic relationships of thoracosaurs. Journal of Vertebrate Paleontolgy, 24:610-633. doi:10.1671/0272-4634(2004)024[0610:ANLCGC]2.0.CO;2

Brochu, C.A. 2006. Osteology and phylogenetic significance of Eosuchus minor (Marsh 1870), new combination, a longirostrine crocodylian from the Late Paleocene of North America. Journal of Paleontology, 80:162-186. doi:10.1666/00223360(2006)080[0162:OAPSOE]2.0.CO;2

Brochu, C.A. 2011. Phylogenetic relationships of Necrosuchus ionensis Simpson, 1937 and the early history of caimanines. Zoological Journal of the Linnean Society, 163:228-256. doi:10.1111/j.1096-3642.2011.00716.x

Brochu, C.A. 2013. Phylogenetic relationships of Paleogene ziphodont eusuchians and the status of Pristichampsus Gervais, 1853. Earth and Environmental Science Transactions of the Royal Society of Edinburgh, 103:521-550. doi:10.1017/ S1755691013000200

Brochu, C.A.; Nieves-Rivera, A.M.; Vélez-Juarbe, J.; Daza-Vaca, J.D. \& Santos, H. 2007. Tertiary crocodylians from Puerto Rico: Evidence for Late Tertiary endemic crocodylians in the West Indies? Geobios, 40:51-59. doi:10.1016/j.geobios.2005.10.008 
Buffetaut, E. 1985. The place of Gavialis and Tomistoma in Eusuchian evolution: a reconcialiation of paleontological and bichemical data. Neues Jahrbuch fur Geologie und Palaontologie, 12:707-716.

Campos, D.A.; Alves, E.D.O. \& Campos, D.R.B. 1976. Localidades fossilíferas da Folha SC.19 Rio Branco. In: L.L. Silva; M. Rivetti; J.O. Del'arco; L.F.G. Almeida; A.M. Dreher \& C.C.G. Tassinari (eds.) Geologia, Rio de Janeiro, Projeto RadamBrasil, p. 65-79 (Levantamento de recursos naturais 12).

Caputo, M.; Rodrigues, V. \& Vasconcelos, D. 1971. Litoestratigrafia da bacia do rio Amazonas. Rio de Janeiro, Petrobras-Renor, 71 p. (Relatório Técnico Interno 641).

Catuneanu, O. et al. 2009. Towards the standardization of sequence stratigraphy. Earth-Science Reviews, 92:1-33. doi10.1016/j. earscirev.2008.10.003

Conrad, J.L.; Jenkins, K.; Lehmann, T.; Manthi, F.K.; Peppe, D.J.; Nightingale, S.; Cossette, A.; Dunsworth, H.M.; Harcourt-Smith, W.E.H. \& Mcnulty, K.P. 2013. New specimens of 'Crocodylus' pigotti (Crocodylidae) from Rusinga Island, Kenya, and generic reallocation of the species. Journal of Vertebrate Paleontology, 33:629-646. doi:10.1080/02724634.2013.743404

Cozzuol, M.A. 2006. The Acre vertebrate fauna: age, diversity, and geography. Journal of South American Earth Sciences, 21:185203. doi:10.1016/j.jsames.2006.03.005

Cunha, P.R.C. 2007. Bacia do Acre. Boletim Geociências Petrobras, 15:207-215.

Delfino, M. \& de Vos, J. 2010. A revision of the Dubois crocodylians, Gavialis bengawanicusand Crocodylus ossifragus, from the Pleistocene Homo erectus beds of Java. Journal of Vertebrate Paleontology, 30:427-441. doi:10.1080/02724631003617910

Delfino, M.; Piras, P. \& Smith, T. 2005. Anatomy and phylogeny of the gavialoid crocodylian Eosuchus lerichei from the Paleocene of Europe. Acta Palaeontologica Polonica, 50:565-580.

Delfino, M. \& Rook, L. 2008. African crocodylians in the Late Neogene of Europe: a revision of Crocodylus bambolii Ristori, 1890. Journal of Paleontology, 82:336-343. doi:10.1666/06-079.1

Duarte, K.S. 2011. Levantamentos Exploratórios da ANP na Bacia do Acre. Revista Técnico-Cientifica da ANP, 1:4-33.

Fortier, D.C.; Souza-Filho, J.P.; Guilherme, E.; Maciente, A.A.R. \& Schultz, C.L. 2014. A new specimen of Caiman brevirostris (Crocodylia, Alligatoridae) from the Late Miocene of Brazil. Journal of Vertebrate Paleontology, 34:820-834. doi:10.1080 /02724634.2014.838173

Gasparini, Z. 1968. Nuevas restos de Rhamphostomopsis neogaeus (Burm.) Rusconi 1933 (Reptilia, Crocodilia) del "Mesopotamiense" (Plioceno medio-superior) de Argentina. Ameghiniana, 5:299-311.

Hoorn, C. 1994. Fluvial palaeoenvironments in the Amazonas Basin (early Miocene-early middle Miocene, Colombia). Palaeogeography, Palaeoclimatology, Palaeoecology, 109:1-54. doi:10.1016/0031-0182(94)90117-1

Hoorn, C. et al. 2010. Amazonia through Time: Andean Uplift, Climate Change, Landscape Evolution, and Biodversity. Science, 330:927-931. doi:10.1126/science. 1194585

Hsiou, A.S. \& Albino, A.M. 2009. Presence of the genus Eunectes (Serpentes, Boidae) in the Neogene of Southwestern Amazonia, Brazil. Journal of Herpetology, 43:612-619. doi: 10.1670/08295.1

Hsiou, A.S.; Albino, A.M. \& Ferigolo, J. 2009. First lizard remains (Teiidae) from the Miocene of Brazil (Solimões Formation). Revista Brasileira de Paleontologia, 12:225-230. doi:10.4072/ rbp.2009.3.05
Jouve, S.; Bardet, N.; Jalil, N.; Suberbiola, X.P.; Bouya, B. \& Amaghzaz, M. 2008. The oldest African crocodylian: phylogeny, paleobiogeography, and differential survivorship of marine reptiles through the Cretaceous-Tertiary boundary. Journal of Vertebrate Paleontology, 28:409-421. doi: 10.1671/0272-4634(2008)28[409:TOACPP]2.0.CO;2

Jouve, S.; Iarochene, M.; Bouya, B. \& Amaghzaz, M. 2006. New material of Argochampsa krebsi (Crocodylia: Gavialoidea) from the Lower Paleocene of the Oulad Abdoun Basin (Morocco): phylogenetic implications. Geobios, 39:817-832. doi:10.1016/j. geobios.2005.07.003

Kotsakis, T.; Delfino, M. \& Piras, P. 2004. Italian Cenozoic crocodylians: taxa, timing and palaeobiogeographic implications. Palaeogeography, Palaeoclimatology, Palaeoecology, 210:6787. doi:10.1016/j.palaeo.2004.03.013

Langston, W.Jr. 1965. Fossil crocodylians from Colombia and the Cenozoic history of the Crocodilia in South America. University of California Publications in Geological Sciences, 52:1-168.

Langston, W.Jr. 2008. Notes on a partial skeleton of Mourasuchus (Crocodylia, Nettosuchidae) from the Upper Miocene of Venezuela. Arquivos do Museu Nacional, 66:125-143.

Langston, W.Jr. \& Gasparini, Z. 1997. Crocodylians, Gryposuchus, and the South Americans gavials. In: R.F. Kay; R.H. Madden; R.L. Cifelli \& J.J. Flynn (eds.) Vertebrate Paleontology in the Neotropics: The Miocene Fauna of La Venta, Colombia, Smithsonian Institution, p. 113-154.

Latrubesse, E.M.; Cozzuol, M.; Silva-Caminha, S.A.F.; Rigsby, C.A.; Absy, M.L. \& Jaramillo, C. 2010. The Late Miocene paleogeography of the Amazon Basin and the evolution of the Amazon River system. Earth-Science Reviews, 99:99-124. doi:10.1016/j.earscirev.2010.02.005

Latrubesse, E.M. \& Rancy, A. 1998. The late quaternary of the upper Juruá River, southwestern Amazonia, Brazil: geology and vertebrate paleontology. In: J. Rabassa \& M. Salemme (eds.) Quaternary of South America and Antarctic Penisula, A.A. Balkema, p. 27-46.

Lull, R.S. 1944. Fossil Gavials from North India. American Journal of Science, 242:417-430.

Moraes-Santos, H.; Bocquentin-Villanueva, J. \& Toledo, P.M. 2011. New remains of a gavialoid crocodylian from the late Oligoceneearly Miocene of the Pirabas Formation, Brazil. Zoological Journal of the Linnean Society, 163:132-139. doi:10.1111/j.10963642.2011.00710.x

Miall, A.D. 1985. Architectural-element analysis: a new method of facies analysis applied to fluvial deposits. Earth-Science Reviews, 22:261-308. doi:10.1016/0012-8252(85)90001-7

Oliveira, C.M.M. 1994. Estilos estruturais e evolução tectônica da Bacia do Acre. Universidade Federal de Ouro Preto, M.Sc. thesis, $206 \mathrm{p}$.

Prasad, G.V.R. \& de Broin, F.L. 2002. Late Cretaceous crocodile remains from Naskal (India): comparisons and biogeographic affinities. Annales de Paléontologie, 88:19-71. doi:10.1016/ S0753-3969(02)01036-4

Price, L.I. 1964. Sobre o crânio de um grande crocodilídeo extinto do Alto de Rio Juruá, Estado do Acre. Anais da Academia Brasileira de Ciências, 56:59-66.

Price, L.I.; Campos, D.A. \& Campos, D.R.B. 1977. Localidades fossilíferas das Folhas SB.18 Javari e SC.18 Contamana. In: A.M. Barros; E.D.O. Alvez; J.F.V. Araujo; M.I.C. Lima \& C.A.C. Fernandes (eds.) Geologia, Rio de Janeiro, Projeto RadamBrasil, p. 17-103 (Levantamento de recursos naturais 13). 
Riff, D. \& Aguilera, O.A. 2008. The world's largest gharials Gryposuchus: description of G. croizati n. sp. (Crocodylia, Gavialidae) from the Upper Miocene Urumaco Formation, Venezuela. Paläontologische Zeitschrift, 82:178-195. doi:10.1007/BF02988408

Riff, D.; Romano, P.S.R.; Oliveira, G.R. \& Aguilera, O.A. 2010. Neogene Crocodile and Turtle Fauna in Northern South América. In: C. Hoorn \& F. Wesselingh (eds.) Amazonia, Landscape and Species Evolution: A Look into the Past, Wiley-Blackwell, p. 259-280.

Salas-Gismondi, R.; Antoine, P.O.; Baby. P.; Brusset, S.; Benammi, M.; Espurt, N.; Franceschi, D.; Pujos, F.; Tejada, J. \& Urbina, M. 2007. Middle Miocene crocodiles from the Fitzcarrald Arch, Amazonian Peru. Cuadernos del Museo Geominero, 8:355-360.

Salas-Gismondi, R.; Flynn, J.J.; Baby, P.; Tejada-Lara, J.V.; Wesselingh, F.P. \& Antoine, P.O. 2015. A Miocene hyperdiverse crocodylian community reveals peculiar trophic dynamics in proto-Amazonian mega-wetlands. Proceedings of the Royal Society B, 282:20142490. doi:10.1098/rspb.2014.2490

Sato, T.; Konishi, T.; Hirayama, R. \& Caldwell, M.W. 2012. A Review of the Upper Cretaceous marine reptiles from Japan. Cretaceous research, 37:319-340. doi:10.1016/j.cretres.2012.03.009
Scheyer, T.M.; Aguilera, O.A.; Delfino, M.; Fortier, D.C.; Carlini, A. A.; Sánchez, R.; Carrillo-Briceño, J.D.; Quiroz, L. \& Sánchez-Villagra, M.R. 2013. Crocodylian diversity peak and extinction in the late Cenozoic of the northern Neotropics. Nature Communications, 4:1907. doi:10.1038/ncomms 2940

Scheyer, T.M. \& Moreno-Bernal, J.W. 2010. Fossil Crocodylians from Venezuela in the context of South American Faunas. In: M.R. Sánchez-Villagra; O.A. Aguilera \& A.A. Carlini (eds.) Urumaco \& Venezuelan Paleontology, Indiana University Press, p. 192-213.

Tineo, D.E.; Bona, P.; Perez, L.M.; Vergani, G.D.; González, G.; Poire, D.G.; Gasparini, Z.N. \& Legarreta, P. 2014. A giant crocodylian Mourasuchus (Alligatoridae, Caimaninae) in shallow lacustrine environments of the Yecua Formation (late Miocene) of Chaco Basin, Bolivia: palaeoenvironmental and palaeogeographic implications. Alcheringa: An Australasian Journal of Palaeontology, 39:224-235. doi:10.1080/0311551 8.2015 .967162

Received in June, 2015; accepted in May, 2016. 